\title{
ECONOMIC AND ENERGY VIABILITY OF SUNFLOWER IRRIGATED CROP
}

\author{
Eder P. Gomes ${ }^{1}$, Arthur C. Sanches ${ }^{2 *}$, Edéria P. G. de Azevedo ${ }^{3}$, Luciano O. Geisenhoff ${ }^{1}$, Rodrigo A. Jordan ${ }^{1}$ \\ ${ }^{2 *}$ Corresponding author. Universidade de São Paulo-ESALQ/USP, Piracicaba, Brasil. E-mail: arthur_camiato@hotmail.com
}

\section{KEYWORDS}

Helianthus annuus L., operating cost of production, energy depreciation, central pivot.

\begin{abstract}
This study was carried out with the objective of assessing grain yield, economic analys is and energy balance of three sunflower genotypes with and without irrigation. The experiment was installed in the Experimental Farm of the Faculty of Agrarian Sciences of the Federal University of Grande Dourados in the 2011/2012 and 2012/2013 harvests in Dourados-MS, Brazil. The experimental design used was a random complete block design with subdivisions, with and without irrigation (plots), with three genotypes (subplots) and four replications, constituting 24 plots. There were no differences in productivity among the genotypes. The irrigation increased the operational cost of the sunflower crop production, but it did not economically obstruct the activity, due to the increase of productivity of $74.5 \%$ and $30 \%$ in the harvests of $2011 / 2012$ and 2012/2013. The energy ratios of the sunflower crop were not altered by irrigation, equal to 5.7 and 8.7 in the harvests of 2011/2012 and 2012/2013, respectively.
\end{abstract}

\section{INTRODUCTION}

Among the several technologies developed for the sunflower production, the appropriate choice of genotype with high grain y ield comprises the main component of the crop production system (Porto et al., 2007). Despite the tolerance to water deficit when compared to other annual crops, sunflower is sensitive to the availability of water in the soil, increasing grain yield under irrigation (Gomes et al., 2012).

The sunflower culture shows national average productivity of $1500 \mathrm{~kg} \mathrm{ha}$ (AGRIANUAL, 2012). However, if adequately managed, the productivity may increase to 1500 to $2200 \mathrm{~kg} \mathrm{ha}^{-1}$ (Dos Santos et al., 2016; Oliveira et al., 2014; Porto et al., 2007). Under irrigation, grain yield is generally in the range of 2200 to $3000 \mathrm{~kg} \mathrm{ha}^{-}$ (Biscaro et al., 2008; Go mes et al., 2010; Guedes Filho et al., 2015; Schwerz et al., 2015), and can reach more than $4000 \mathrm{~kg} \mathrm{ha}^{-1}$ in favorable soil and climatic conditions (Go mes et al., 2010; De Aquino et al., 2013), being able to reach $4.000 \mathrm{~kg} \mathrm{ha}^{-1}$ in favorable edaphoclimatic conditions (Karam et al., 2007; Anastasi et al., 2010; Gomes et al., 2012).

Since the adoption of the National Program for the Production and Use of Biodiesel, introduced in 2005, it has been growing the oilseed production in the country, especially in family agriculture (there are incentives to the overwhelming power plants that buy from this sector); however, different from the expectation of diversification, soybean cultivation continues to predominate (Silva, 2013). W ith technical assistance and structured production chain, sunflower cultivation could become an interesting alternative in the summer harvest, with higher oil productivity (Jasper et al., 2010) and lower production costs in relation to soybean (AGRIANUAL, 2012).

In addition to economic viability, studies of the energy ratio in different production systems can provide subsidies for the Brazilian agriculture to become increasingly sustainable (Capelles so \& Cazella, 2013). The energetic ratio can be obtained by the energy value of the productivity on all the energy expenditures coming from the implantation of the culture, being an important instrument of technological choice (Assenheimer et al., 2009), avoiding and replacing the genotypes and productive systems with relation less than one (Albuquerque et al., 2007).

Irrigation is among the technologies that most contributes to the increase of productivity (Lira et al., 2015; Pereira et al., 2015); however, it also increases the input (consumption) of energy in the agricultural system. In this sense, some studies have been carried out over the last years aiming to analyze the energetic ratio of irrigated crops (Gomes et al., 2013, Jordan et al., 2012a; Jordan et al., 2012b).

This experiment was developed with the objective of performing economic analysis and energetic ratio of

\footnotetext{
${ }^{1}$ Universidade Federal da Grande Dourados - UFGD/ Dourados - MS, Brasil.

${ }^{3}$ Universidade Estadual Paulista - UNESP/ Botucatu - SP, Brasil.

Received in: 2-1-2017

Accepted in: 11-20-2017
} 
sunflower genotypes for two years, with and without irrigation, in the region of Dourados, Mato Grosso do Sul, Brazil.

\section{MATERIAL AND METHODS}

The experiment was carried out at the Experimental Farm of the Faculty of Agricultural Sciences - FCA, Federal University of Grande Dourados - UFGD, in Dourados, Mato Grosso do Sul, located at the geographical coordinates $22^{\circ} 12^{\prime}$ south latitude, $54^{\circ} 56^{\prime}$ west longitude and average altitude of $452 \mathrm{~m}$.

The climate of the region is classified by Köppen as Cwa (humid mesothermic with rainy summer). The soil of the experimental area is classified as Red Latosol Distroferric (EMBRAPA, 2006). The values of the chemical analysis of the soil referring to the depth of 0 $0.20 \mathrm{~m}$ are found in Table 1 .

TABLE 1. Chemical analys is of the soil in the $0-0.20$ m layer of the experiment with irrigated and non-irrigated sunflower in the years $2011 / 2012$ and 2012/2013.

\begin{tabular}{|c|c|c|c|c|c|c|c|c|}
\hline & $\mathrm{pH}\left(\mathrm{CaCl}_{2}\right)$ & $\mathrm{P}$ & $\mathrm{V}$ & $\mathrm{H}^{+}+\mathrm{Al}^{3+}$ & $\mathrm{Al}^{3+}$ & $\mathrm{Ca}^{2+}$ & $\mathrm{Mg}^{2+}$ & $\mathrm{K}^{+}$ \\
\hline Experiment & & $\mathrm{mg} \mathrm{\textrm {dm } ^ { - 3 }}$ & $\%$ & \multicolumn{5}{|c|}{ 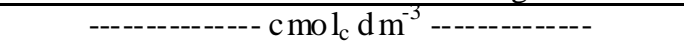 } \\
\hline $2011 / 2012$ & 5.00 & 15.20 & 62.0 & 5.76 & 0.08 & 6.66 & 2.21 & 0.53 \\
\hline $2012 / 2013$ & 5.00 & 11.20 & 64.5 & 4.90 & 0.05 & 6.59 & 2.25 & 0.37 \\
\hline
\end{tabular}

For two years, the experimental area was prepared with plowing and harrowing, 30 days before sowing, incorporating $1500 \mathrm{~kg} \mathrm{ha}^{-1}$ and $1000 \mathrm{~kg} \mathrm{ha}^{-1}$ of dolomitic limestone PRNT $80 \%$, respectively, aiming to raise the base saturation by $70 \%$ (V). Afterwards, the irrigation system and the tensiometers were installed. In the sowings carried out on October $22^{\text {nd }}, 2011$ and October $31^{\text {st }}, 2012$, $150 \mathrm{~kg} \mathrm{ha}^{-1}$ of the 8-20-20 formulation and $1 \mathrm{~kg} \mathrm{ha}^{-1}$ of boron in the form of borax were also applied. In the cover fertilization, 40 days after sowing (DAS), $50 \mathrm{~kg} \mathrm{ha}^{-1}$ of nitrogen in the form of urea was also applied.

The same experimental design was utilized in both years: randomb locks, in schemes of subdivided plots, with and without irrigation (plots), with three genotypes (subplots) and four repetitions, comprising 24 plots. The plots were implanted with an area of $36 \mathrm{~m}^{2}$, (15 m x 2.4 $\mathrm{m})$, with four plant rows spaced in $0.60 \mathrm{~m}$ and with spacing between plants of $0.2 \mathrm{~m}$. The subplots were implanted with $12 \mathrm{~m}^{2}(5 \mathrm{~m} \times 2.4 \mathrm{~m})$. It was utilized genotypes from EMBRAPA: BRS 321, EMBRAPA 122 V2000 and BRS 323.

The irrigation system was assembled using three lines of dripping tapes between the plant rows, with spacing between the emitters of $0.40 \mathrm{~m}$ and drain of $3.65 \mathrm{~L}$ $\mathrm{h}^{-1} \mathrm{~m}^{-1}$, to $100 \mathrm{kPa}$ of service pressure, obtaining an application intensity of $6.1 \mathrm{~mm} \mathrm{~h}^{-1}$. The service pressure was maintained by means of a drawer register installed next to a pressure gauge with a resolution of $5 \mathrm{kPa}$.

Irrigation management was done from tensiometers installed at $0.2 \mathrm{~m}$ depth. The irrigation depth (ID) was determined by the difference between volumetric moisture in the field capacity $\left(\theta_{\mathrm{cc}}\right)$ and the current volumetric humidity $\left(\theta_{\mathrm{a}}\right)$, multiplied by the effective depth of the root, equal to $400 \mathrm{~mm}$. The volumetric humidity was estimated by means of the soil water retention curve $(\theta a=0.4394 \gamma$ $\left.0.077 ; \mathrm{R}^{2}=0.981\right)$. It was considered as soil water stress in the field capacity $\left(\gamma_{\mathrm{cc}}\right)$ the value of $6 \mathrm{kpa}$. Irrigation was suspended at 90 DAS (R8 stage - back of the yellowish chapter and green bracts).

Table 2 shows the values of temperature, relative humidity, rainfall and irrigation in the experimental periods. Irrigated treatments received $270.9 \mathrm{~mm}$ and 290.5 $\mathrm{mm}$ of water depth in the first and second year, respectively.

TABLE 2. Temperature (T), relative hu midity ( $\mathrm{RH})$, precipitation $(\mathrm{P})$ and irrigation (I) during experimental cycles of sunflower cultivation *.

\begin{tabular}{|c|c|c|c|c|c|c|c|c|}
\hline $\begin{array}{l}\text { Period } \\
\text { DAS }\end{array}$ & $\begin{array}{l}\mathrm{T}_{11 / 12} \\
\left({ }^{\circ} \mathrm{C}\right)\end{array}$ & $\begin{array}{l}\mathrm{T}_{12 / 13} \\
\left({ }^{\circ} \mathrm{C}\right)\end{array}$ & $\begin{array}{c}\mathrm{UR}_{11 / 12} \\
(\%)\end{array}$ & $\begin{array}{c}\mathrm{UR}_{12 / 13} \\
(\%)\end{array}$ & $\begin{array}{l}P_{11 / 12} \\
(\mathrm{~mm})\end{array}$ & $\begin{array}{l}\mathrm{P}_{12 / 13} \\
(\mathrm{~mm})\end{array}$ & $\begin{array}{l}\mathrm{I}_{11 / 12} \\
(\mathrm{~mm})\end{array}$ & $\begin{array}{l}\mathrm{I}_{12 / 13} \\
(\mathrm{~mm})\end{array}$ \\
\hline $0-20$ & 24.2 & 25.5 & 65.6 & 69.7 & $87.8(5)$ & $50.0(4)$ & 0 & 39.7 \\
\hline $21-40$ & 24.4 & 26.9 & 66.3 & 72.6 & $139.6(5)$ & $112.6(4)$ & 59.8 & 75 \\
\hline $41-60$ & 25.1 & 26.5 & 61.1 & 75.2 & $33.8(2)$ & $48.6(4)$ & 97.5 & 76.8 \\
\hline $61-90$ & 26.4 & 25.1 & 66.9 & 73.8 & $110.8(3)$ & $76.6(4)$ & 113.6 & 99.0 \\
\hline $91-110$ & 25.8 & 25.7 & 73.1 & 76.1 & $104.4(3)$ & $141.1(5)$ & 0 & 0 \\
\hline Average: & 25.2 & 25.9 & 66.6 & 73.5 & 476.4 & 428.9 & 270.9 & 290.5 \\
\hline
\end{tabular}

At the end of the cycles, on February $10^{\text {th }}, 2012$ and February $18^{\text {th }}, 2013,06$ plants were removed per subplot with the objective of evaluating productivity, correcting seed moisture to $13 \%$. The productivity data were submitted to analysis of variance and Tukey test at $5 \%$ of probability.

The economic analysis was made based on the total production operating cost (TPO) and the effective operating cost (EOC), using market quotations. In the composition of the EOC it was considered the expenses with inputs, labor, electric energy in the case of irrigation, tax and revenue expenses. TPO was obtained by adding EOC plus capital depreciation (Martin et al., 1994).

$$
\mathrm{EOC}=\mathrm{CI}+\mathrm{MC}+\mathrm{TOR}+\mathrm{EOR}+L C+\mathrm{CE}
$$

where,

EOC - effective operating cost, $\mathrm{R} \$ \mathrm{ha}^{-1}$;

$\mathrm{CI}$ - cost of inputs, $\mathrm{R} \$ \mathrm{ha}^{-1}$; 
$\mathrm{MC}$ - maintenance cost, $\mathrm{R} \$ \mathrm{ha}^{-1}$;

TOR - tax on revenue, $\mathrm{R} \$ \mathrm{ha}^{-1}$;

EOR - expenditure on revenue, $\mathrm{R} \$ \mathrm{ha}^{-1}$;

$\mathrm{LC}$ - labor cost, $\mathrm{R} \$ \mathrm{ha}^{-1}$,

$\mathrm{CE}$ - cost of electricity, $\mathrm{R} \$ \mathrm{ha}^{-1}$

$\mathrm{TPO}=\mathrm{EOC}+\mathrm{CD}$

where,

$\mathrm{TPO}$ - total production operational cost, $\mathrm{R} \$ \mathrm{ha}^{-1}$;

EOC - effective operational cost, $\mathrm{R} \$ \mathrm{ha}^{-1}$,

$\mathrm{CD}$ - capital depreciation, $\mathrm{R} \$ \mathrm{ha}^{-1}$

Because it is a self-propelled system (central pivot simulation), it was not considered a labor increase due to irrigation. In the region there is still no charge for the use of water.

From the applied irrigation depth, the simulation was based on the power, mechanical efficiency and power factor of the electric motor of a central pivot water pump for 100 ha with flat topography, with electrical power required for pumping the order of $1.472 \mathrm{~kW} \mathrm{ha}^{-1}$, which is considered in the calcu lation of the energy cost. It was also considered an application intensity of $0.43 \mathrm{~mm} \mathrm{~h}^{-1}$ and maintenance cost (MC) for central pivot estimated at $1.5 \%$ per year (Frizzone et al., 2005). The electric power was taxed according to the green horticultural price, adopting the energy prices (EP) established by CERGRAND (Cooperative of Energizing and Rural Development of Grande Dourados) equal to $\mathrm{R} \$ 0.2103 \mathrm{kWh}^{-1}$ in the offpeak period with a discount of $80 \%$ from $9: 30 \mathrm{pm}$ to 6:00am (R $\$ 0.0421 \mathrm{kWh}^{-1}$ ). The monthly contracted demand rate (CDR), equal to $\mathrm{R} \$ 13.96 \mathrm{~kW}^{-1}$, was converted to $\mathrm{R} \$ 20.55 \mathrm{ha}^{-1}$ month $^{-1}$. It was considered a variable watering time for water depth equal to $9 \mathrm{~mm}$, with irrigation time of 21 hours, avoiding peak time $(5: 30 \mathrm{pm}$ to $8: 30 \mathrm{pm}$ ) and obtaining, by weighted average, EP equal to $\mathrm{R} \$ 0.1424 \mathrm{kWh}^{-1}$. The energy cost was estimated as follows:

$$
\mathrm{CE}=(1.472 \times \mathrm{EP} \times \mathrm{IT})+C D R
$$

where,

$$
\begin{aligned}
& \mathrm{EP} \text { - energy price, } \mathrm{R} \$ \mathrm{~kW} \mathrm{~h}{ }^{-1} \text {; } \\
& \text { IT - Irrigation time per production cycle, } \mathrm{h} \text {, } \\
& \mathrm{CDR} \text { - contracted demand rate }\left(\mathrm{R} \$ \mathrm{ha}^{-1}\right)
\end{aligned}
$$

The effective operating profit (EOP), which represents the economic viability in the short term, was obtained by the difference between the revenue (REV) and the effective operating cost (EOC):

$$
\mathrm{EOP}=\mathrm{REV}-\mathrm{EOC}
$$

where,

$$
\begin{aligned}
& \text { EOP - effective operational profit, } \mathrm{R} \$ \mathrm{ha}^{-1}, \\
& \mathrm{REV} \text { - revenue, } \mathrm{R} \$ \mathrm{ha}^{-1}
\end{aligned}
$$

Total operating profit (TOP), which represents long-term economic viability, was obtained by the difference between gross revenue (GR) and total production operating cost (TPO):

$$
T O P=R E V-T P O
$$

where,

TOP - Total operational profit $\mathrm{R} \$ \mathrm{ha}^{-1}$

Capital depreciation (CD) was calculated using the capital recovery factor method (Tokairin et al., 2014), disregarding the residual value. In the case of irrigated plots, the irrigation system of the Central- Pivot type was considered (being the most used in irrigation of crops in the region), admitting a value of $\mathrm{R} \$ 5500.00 \mathrm{ha}^{-1}$, according to average practiced price in 2011, using an interest rate (R) of $7.5 \%$ per year. For the Central-Pivot, it was used a 20-year life span (n) and use capacity equal to $2000 \mathrm{~h} \mathrm{year}^{-1}$ (Frizzone et al., 2005). For the other machines and equipment, life values were adopted according to Pacheco (2000).

$$
\mathrm{CD}=\left[\frac{\mathrm{C} \times \mathrm{R}(\mathrm{R}+1)^{\mathrm{n}}}{(1+\mathrm{R})^{\mathrm{n}}-1}\right] \times \mathrm{F}
$$

where,

$\mathrm{CD}$ - capital depreciation, $\mathrm{R} \$ \mathrm{ha}^{-1}$;

$\mathrm{C}$ - capital cost acquisition, $\mathrm{R} \$ \mathrm{ha}^{-1}$;

$\mathrm{R}$ - annual interest rate, decimal;

$\mathrm{n}$ - life span, years,

F - ratio between hours of use per cycle and hours per year, decimal

The energy viability analysis was performed using energy relations using the process analysis methodology (Hülsbergen et al., 2001):

$$
\mathrm{ER}=\frac{\mathrm{EE}}{\mathrm{UE}}
$$

where,

ER - energetic relationship, dimensionless;

EE - extracted energy, $\mathrm{MJ} \mathrm{ha}^{-1}$,

UE - utilized energy, $\mathrm{MJ}^{-1}$

The UE was estimated as follows:

$$
\mathrm{UE}=\mathrm{ED}+\mathrm{EI}+\mathrm{EML}+\mathrm{EEL}
$$

where,

ED - Energy depreciation of equip ment, $\mathrm{MJ} \mathrm{ha}^{-1}$; EI - Energy de mand for the use of inputs, $\mathrm{MJ} \mathrm{ha}^{-1}$; EMO - energy employed in manual labor, $\mathrm{MJ} \mathrm{ha}^{-1}$, EEL - energy consumed in the form of electricity, $\mathrm{MJ} \mathrm{ha}^{-1}$

The energy required for the use of inputs was adopted according to values recommended by Hülsbergen et al. (2001) and Melo et al. (2007). Energy depreciation 
(ED) was estimated as recommended by Assenheimer et al. (2009), in the case of non-propelled equipment (imple ments):

$$
\mathrm{ED}_{\mathrm{NPE}}=\frac{57.2 \mathrm{M}}{\mathrm{n}} \mathrm{H}
$$

In the case of the propelled equipment (tractor and center pivot) the ED was calcu lated as follows:

$$
\mathrm{ED}_{\mathrm{PE}}=\frac{69.8 \mathrm{M}}{\mathrm{n}} \mathrm{H}
$$

where,

$\mathrm{ED}_{\mathrm{NPE}}{ }^{-}$energy depreciation of non-propelled equipment, $\mathrm{MJ} \mathrm{ha}^{-1}$;

$\mathrm{ED}_{\mathrm{PE}^{-}}{ }^{-}$energy depreciation of propelled equipment, $\mathrm{MJ} \mathrm{ha}^{-1}$;

M - mass of machinery and equipment, $\mathrm{kg}$,

$\mathrm{n}$ - life span, $\mathrm{h}$

$\mathrm{H}$ - usage time per cycle, $\mathrm{h}$
The mass of machines and equipment was adopted as recommended by Assenheimer et al. (2009) and the life span according to Chechetto et al. (2010). The mass of the central pivot irrigation system, equal to $57.2 \mathrm{~kg} \mathrm{~m}^{-1}$, was obtained according to information from Valmont Industry and Commerce Ltd.

\section{RES ULTS AND DISCUSS IONS}

Productivity was affected by irrigation and harvests ( $\mathrm{P}<0.05)$ independent of the cultivated genotype (P> 0.05). The highest yields were obtained in the 2012/2013 crop (Table 3), probably due to more favorable edaphoclimatic conditions (Tables 1 and 2), such as elevation of base saturation $(\mathrm{V})$, higher temperature and better distribution of rainfall, mainly from 41 to 60 DAS (stage R4 - opening of the inflorescence).

The yields of sunflower obtained under irrigation are above the values found by Guedes Filho et al. (2015) and Biscaro et al. (2008), both in second crop cultivation (small harest). In the 2012/2013 harvest, productivity under irrigation approached the mark of $4.000 \mathrm{~kg} \mathrm{ha}^{-1}$, surpassed in other surveys conducted in the first harvest (Anastasi et al., 2010, Gomes et al., 2012).

\begin{tabular}{|c|c|c|c|c|}
\hline Systems / crops & BRS 323 & BRS 321 & E122 V2000 & Averages** \\
\hline & \multicolumn{4}{|c|}{ 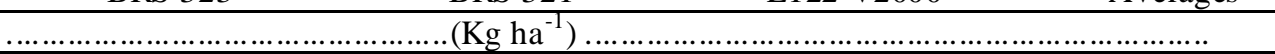 } \\
\hline With irrigation & $3046 \mathrm{a}$ & $2955 \mathrm{a}$ & $3253 \mathrm{a}$ & $3085 \mathrm{a}$ \\
\hline Without irrigation & $2238 \mathrm{~b}$ & $1489 \mathrm{~b}$ & $1576 \mathrm{~b}$ & $1768 \mathrm{~b}$ \\
\hline Crop $2011 / 2012$ & $2642 \mathrm{~A}$ & $2222 \mathrm{~A}$ & $2415 \mathrm{~A}$ & $2426 \mathrm{~A}$ \\
\hline With irrigation & $3328 \mathrm{a}$ & $4375 \mathrm{a}$ & $3867 \mathrm{a}$ & $3857 \mathrm{a}$ \\
\hline Without irrigation & $2872 b$ & $2879 \mathrm{~b}$ & $3144 b$ & $2965 b$ \\
\hline Crop 2012/2013 & $3100 \mathrm{~B}$ & $3627 \mathrm{~B}$ & $3501 \mathrm{~B}$ & $3411 \mathrm{~B}$ \\
\hline
\end{tabular}

TABLE 3. Productivity of sunflower genotypes* in the 2011/2012 and 2012/2013 harvests with and without irrigation.

* There weren't significant differences in yield between genotypes.

** Meaningful differences between systems (small letters) and between crops (capital letters).

Considering the irrigation depths applied in the two years of experiment equal to $270.9 \mathrm{~mm}$ in $2011 / 2012$ and $290.5 \mathrm{~mm}$ in 2012/2013 (Table 2), adopting application intensity of $0.43 \mathrm{~mm} \mathrm{~h}^{-1}$, it was obtained in their respective years the irrigation time (IT) equal to 630 and 676 hours. Applying the equation 03 , considering the energy price (EP) of R $\$ 0.1424 \mathrm{kWh}^{-1}$ and the contracted demand cost (CDC) equal to $\mathrm{R} \$ 20.55 \mathrm{ha}^{-1} \mathrm{month}^{-1}$, during the harvests 2011/2012 and 2012/2013 the energy costs (EC) for irrigation was equal to R\$234.81 ha $\mathrm{ha}^{-1}$ and $\mathrm{R} \$ 244.45 \mathrm{ha}^{-1}$, respectively.

TABLE 4. Prices of Input used in the sunflower crops*.

\begin{tabular}{cccccc}
\hline & Unit ha $^{-1}$ & $\begin{array}{c}\text { Unit price 2011 } \\
(\mathrm{R} \$)\end{array}$ & $\begin{array}{c}\text { Total price 2011 } \\
\left(\mathrm{R} \$ \mathrm{ha}^{-1}\right)\end{array}$ & $\begin{array}{c}\text { Unit price 2012 } \\
(\mathrm{R} \$)\end{array}$ & $\begin{array}{c}\text { Total price 2012 } \\
\left(\mathrm{R} \$ \mathrm{ha}^{-1}\right)\end{array}$ \\
\hline Formulated 8-20-20 (kg) & 150 & 1.149 & 172.35 & 0.996 & 149.40 \\
Dolomitic limestone (kg) & $1500(1000)^{*}$ & 0.083 & 124.50 & 0.130 & 130.00 \\
Urea (kg) & 111 & 1.136 & 126.10 & 1.100 & 122.10 \\
Bórax (kg) & 1 & 4.000 & 4.00 & 4.000 & 4.00 \\
Diesel (L) & 60 & 2.180 & 130.80 & 2.180 & 130.80 \\
Seeds (kg) & 4.6 & 7.500 & 34.50 & 7.500 & 34.50 \\
Desiccant (L) & 3 & 7.100 & 21.30 & 7.000 & 21.00 \\
Inseticide (L) & 0.1 & 56.400 & 5.64 & 75.000 & 7.50 \\
\hline
\end{tabular}

Table 4 shows the prices of the inputs used in sunflower cultivation in the two years of experiment, equal to $\mathrm{R} \$ 619.19$ in 2011 and $\mathrm{R} \$ 599.30$ in 2012. Table 5 shows the capital depreciation of the machinery and implements, equal to $\mathrm{R} \$ 62.10$ per year. The used time of the plow and grid was measured at the site. In the treatments that received irrigation, it was also considered the depreciation of the Central- Pivot type system, equals to $\mathrm{R} \$ 169.83$ in $2011 / 2012$ and $\mathrm{R} \$ 181.16$ in $2012 / 2013$. 
TABLE 5. Capital depreciation and maintenance cost of machines, implements and irrigation system.

\begin{tabular}{|c|c|c|c|c|c|}
\hline $\begin{array}{l}\text { Machines and } \\
\text { Implementation }\end{array}$ & $\begin{array}{l}\text { Usage of Time } \\
\qquad\left(\mathrm{h} \mathrm{ha}^{-1}\right)\end{array}$ & $\begin{array}{l}\text { Cost } \\
(\mathrm{R} \$)\end{array}$ & Life Span & $\begin{array}{c}\mathrm{CD} \\
\left(\mathrm{R} \$ \mathrm{ha}^{-1}\right)\end{array}$ & $\begin{array}{c}\mathrm{MC}^{* *} \\
\left(\mathrm{R} \$ \mathrm{ha}^{-1}\right)\end{array}$ \\
\hline Scrubber & 0.33 & 18000 & 10 years $\left(200\right.$ h year $\left.^{-1}\right)$ & 2.91 & 1.49 \\
\hline Plow & 2.00 & 6250 & 5 years $\left(400 \mathrm{~h}\right.$ year $\left.{ }^{-1}\right)$ & 3.07 & 3.13 \\
\hline Grid & 0.50 & 15500 & 5 years $\left(400\right.$ h year $\left.^{-1}\right)$ & 1.90 & 1.94 \\
\hline Seed Drill & 0.42 & 24000 & 5 years $\left(240\right.$ h year $\left.^{-1}\right)$ & 4.12 & 4.20 \\
\hline Pulverizer (Spray) & 0.40 & 9300 & 5 years $\left(240\right.$ h year $\left.^{-1}\right)$ & 1.52 & 1.55 \\
\hline Tractor $75 \mathrm{cv}$ & 4.19 & 85000 & 10 years $\left(1000 \mathrm{~h}\right.$ year $\left.^{-1}\right)$ & 32.18 & 16.41 \\
\hline Harvester $140 \mathrm{cv}$ & 0.44 & 380500 & 10 years $\left(1000 \mathrm{~h} \mathrm{year}^{-1}\right)$ & 16.42 & 8.37 \\
\hline Irrigation (Central Pivot) & $630(672 *)$ & $5500 * * *$ & 20 years $\left(2000 \mathrm{~h} \mathrm{year}^{-1}\right)$ & $169.83\left(181.16^{*}\right)$ & $25.99(27.72 *)$ \\
\hline Total with irrigation & & & & 62.10 & 37.09 \\
\hline Total without irrigation & & & $\left(64.81^{\prime}\right.$ & $231.93\left(243.26^{*}\right)$ & 63.08 \\
\hline
\end{tabular}

$(*)$ related to the crop $2012 / 2013 ; * *\left[\left(50 \%\right.\right.$ acquisition cost $(\mathrm{R} \$) \mathrm{x}$ usage of time $\left(\mathrm{h} \mathrm{ha}^{-1}\right) /$ life span $\left.(\mathrm{h})\right]$; $* * *$ cost per hectare

The table 6 shows the average values of productivity (PROD), revenue (REV), tax (TAX) and expenditure on revenue (EOR) for sunflower genotypes, with and without irrigation. The REV was obtained from the prices practiced in the months of February 2012 and 2013, when the sunflower sacks were sold at R\$ 47.32 and R \$ 55.47, respectively.

TABLE 6. Productivity, income, tax and expenses of sunflower cultivation with and without irrigation in the harvests of 2011/2012 and 2012/2013.

\begin{tabular}{|c|c|c|c|c|c|c|c|c|}
\hline Sunflower Genotypes & $\begin{array}{c}\mathrm{PROD}_{11 / 12} \\
\left(\mathrm{~kg} \mathrm{ha}^{-1}\right)\end{array}$ & $\begin{array}{c}\mathrm{PROD}_{12 / 13} \\
\left(\mathrm{~kg} \mathrm{ha}^{-1}\right)\end{array}$ & $\begin{array}{l}\mathrm{REV}_{11 / 12} \\
\left(\mathrm{R} \$ \mathrm{ha}^{-1}\right)\end{array}$ & $\begin{array}{l}\mathrm{REV}_{12 / 13} \\
\left(\mathrm{R} \$ \mathrm{ha}^{-1}\right)\end{array}$ & 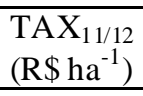 & $\begin{array}{l}\mathrm{TAX}_{12 / 13} \\
\left(\mathrm{R} \$ \mathrm{ha}^{-1}\right)\end{array}$ & $\begin{array}{l}\mathrm{EOR}_{11 / 12} \\
\left(\mathrm{R} \$ \mathrm{ha}^{-1}\right)\end{array}$ & $\begin{array}{l}\mathrm{EOR}_{12 / 13} \\
\left(\mathrm{R} \$ \mathrm{ha}^{-1}\right)\end{array}$ \\
\hline & $3085(51.4)$ & $3857(643)$ & 2432.25 & 3566.72 & 55.94 & 82.03 & 121.61 & 178.34 \\
\hline Without irrigation & $1768(29.5)$ & $2965(49.4)$ & 1395.94 & 2740.22 & 32.11 & 63.03 & 69.78 & 137.01 \\
\hline
\end{tabular}

For the composition of the effective operational cost - EOC (Table 07), the labor expense was considered from the work of two employees in the agricultural operations (4.63 hours each, equal to the time used of the tractor plus harvester - Table $05)$, considering the work hour of each equal to $\mathrm{R} \$ 9.38\left(\mathrm{R} \$ 1500.00\right.$ month $^{-1}$ ), obtaining $\mathrm{R} \$ 86.81 \mathrm{ha}^{-1}$. The revenue tax (TAX) and revenue on expenses (EOR) were obtained by applying percentages of 2.3\% and 5\% of revenues (REC), respectively (equation 01 ).

TABLE 7. Costs and operating profits from sunflower cultivation in the harvests of 2011/2012 and 2012/2013.

\begin{tabular}{|c|c|c|c|c|c|c|c|c|}
\hline $\begin{array}{l}\text { Sunflower } \\
\text { Genotypes }\end{array}$ & $\begin{array}{c}\mathrm{EOC}_{2011 / 12} \\
\left(\mathrm{R} \$ \mathrm{ha}^{-1}\right)\end{array}$ & $\begin{array}{r}\mathrm{EOC}_{2012 / 13} \\
\left(\mathrm{R} \$ \mathrm{ha}^{-1}\right)\end{array}$ & $\begin{array}{r}\mathrm{TPO}_{2011 / 12} \\
\left(\mathrm{R} \$ \mathrm{ha}^{-1}\right) \\
\end{array}$ & $\begin{array}{r}\mathrm{TPO}_{2012 / 13} \\
\left(\mathrm{R} \$ \mathrm{ha}^{-1}\right)\end{array}$ & $\begin{array}{r}\mathrm{EOP}_{2011 / 12} \\
\left(\mathrm{R} \$ \mathrm{ha}^{-1}\right) \\
\end{array}$ & $\begin{array}{r}\mathrm{EOP}_{2012 / 13} \\
\left(\mathrm{R} \$ \mathrm{ha}^{-1}\right)\end{array}$ & $\begin{array}{c}\mathrm{TOP}_{2011 / 12} \\
\left(\mathrm{R} \$ \mathrm{ha}^{-1}\right)\end{array}$ & $\begin{array}{r}\mathrm{TOP}_{2012 / 13} \\
\left(\mathrm{R} \$ \mathrm{ha}^{-1}\right)\end{array}$ \\
\hline & 1181.44 & 1255.74 & 1413.37 & 1499.00 & 1250.81 & 2310.98 & 1018.88 & 2067.72 \\
\hline Without irrigation & 844.98 & 923.24 & 907.08 & 985.34 & 550.96 & 1816.98 & 488.86 & 1754.88 \\
\hline
\end{tabular}

The irrigation increased the effective operating cost (EOC) of production by $41 \%$ and $36 \%$ in the $2011 / 2012$ and 2012/2013 harvests, respectively. The increase in total production operational cost (TPO) with irrigation was $56 \%$ and 52\% in the 2011/2012 and 2012/2013 harvest seasons, respectively. These costs were offset by increased productivity under irrigation, with increases of $127 \%$ and $27 \%$ for effective operational profit (EOP) in the harvests of 2011/2012 and 2012/2013, respectively (equation 04). The total operating profit (TOP) under irrigation obtained an increase of $108 \%$ and $18 \%$ in the harvests of $2011 / 2012$ and 2012/2013, respectively (equation 05).

These results make feasible the irrigation technique in short (EOP) and long term (TOP). Guedes Filho et al. (2015), conducting the sunflower experiment under irrigation with the genotype EMBRAPA 122/V-2000, reached an average productivity of $2494 \mathrm{~kg} \mathrm{ha}^{-1}$ with 100 $\mathrm{kg} \mathrm{ha}^{-1} \mathrm{de} \mathrm{N}$, and observed viability only in the short term. At the time the value of the bag was $\mathrm{R} \$ 31.80$.
At the current conjuncture, it seems unlikely the long term economic inviability for irrigated sunflower cultivation, since only the activity would become impracticable at a price lower than $\mathrm{R} \$ 27.50 \mathrm{a}$ bag, or else (if the price of the bag remains at $\mathrm{R} \$ 50.00$ ) with the productivity less than $30 \mathrm{bags} \mathrm{ha}^{-1}\left(1800 \mathrm{~kg} \mathrm{ha}^{-1}\right)$.

The energy used in sunflower cultivation through inputs was 8564.76 and $7964.76 \mathrm{MJ} \mathrm{ha}^{-1}$ (average value as $8265 \mathrm{MJ} \mathrm{ha}^{-1}$ ), in the harvests of 2011/2012 and $2012 / 2013$, respectively (Table 8 ), that is, $98.8 \%$ of the average energy used (EU) without irrigation (Table 11). Jordan et al. (2012a) also found that inputs were responsible for more than $90 \%$ of the energy demand in sunflower cultivation without irrigation. In general, inputs are mainly responsible for energy demand in conventional agriculture (Checheto et al., 2010; Gomes et al., 2013). 
TABLE 8. Energy demanded for the use of inputs (EI) used in sunflower cultivation.

\begin{tabular}{lcccc}
\hline Input & Unit & Energy Unit $(\mathrm{MJ})$ & ${\text { Quantity }\left(\text { unit ha }^{-1}\right)}$ & EI $\left(\mathrm{MJ}\right.$ ha $\left.^{-1}\right)$ \\
\hline Nitrogen $(\mathrm{N})$ & $\mathrm{kg}$ & 50.3 & 62 & 3118.6 \\
Phosphorum $\left(\mathrm{P}_{2} \mathrm{O}_{5}\right)$ & $\mathrm{kg}$ & 12.6 & 30 & 378 \\
Potassium $\left(\mathrm{K}_{2} \mathrm{O}\right)$ & $\mathrm{kg}$ & 6.8 & 30 & 204 \\
Boron & $\mathrm{kg}$ & 15.35 & 1 & 15.35 \\
Dolomitic Limestone & $\mathrm{kg}$ & 1.2 & $1500\left(1000^{*}\right)$ & 1800 \\
Diesel & $\mathrm{L}$ & 35.5 & 47.7 & 1693.35 \\
Treated seeds & $\mathrm{kg}$ & 25.1 & 4.6 & 115.46 \\
Inseticide & $\mathrm{L}$ & 400 & 0.1 & 40 \\
Desiccant & $\mathrm{L}$ & 400 & 3 & 1200 \\
\hline Total & & & $8564.76\left(7964.76^{* *}\right)$ \\
\hline
\end{tabular}

(*) Quantity used in the 2012/2013 harvest; (**) energy by the use of inputs employed in the 2012/2013 harvest.

The average energy used (EU) to produce the sunflower crop without irrigation was $8365 \mathrm{MJ}^{-1}$ (Table 10), with $100.03 \mathrm{MJ}$ consumed in the form of energy depreciation (Table 9), $9 \mathrm{MJ}$ of energy of hand of (EHO). In the estimation of EHO it was considered a daily requirement (8 hours) of $2000 \mathrm{kcal}(8.38 \mathrm{MJ})$, with 4.3 hours of work (the same as machine hours), employing two employees in agricultural operations.

TABLE 9. Energy depreciation (ED) as a function of the time using machines and equipment used in the cultivation of sunflower in a conventional system.

\begin{tabular}{|c|c|c|c|c|}
\hline Machines - implements & Mass (kg) & Life span (h) & Us age of time $(\mathrm{h})$ & ED (MJ ha') \\
\hline Pulverizer (Spray) & 110 & 1200 & 0.4 & 2.10 \\
\hline Plow & 402 & 2000 & 2 & 22.99 \\
\hline Grid & 1422 & 2000 & 0.5 & 20.33 \\
\hline Seed Drill & 899 & 1200 & 0.42 & 20.02 \\
\hline Cultivator & 493 & 2000 & 0.54 & 7.61 \\
\hline Tractor $75 \mathrm{cv}$ & 899 & 10000 & 3.86 & 24.22 \\
\hline Harvester $140 \mathrm{cv}$ & 899 & 10000 & 0.44 & 2.76 \\
\hline Total & & & & 100.03 \\
\hline
\end{tabular}

Table 10 shows the energy consumed by irrigation in the form of electric energy (EEL) and energy depreciation (ED), adding an average energy demand of $3827 \mathrm{MJ} \mathrm{ha}^{-1}$, that is, an increase in consumption Energy consumption of $45.8 \%$ due to irrigation, main ly because of electricity.

TABLE 10. Energy spend in the form of electricity (EEL) and energy depreciation (ED) in the irrigation system

\begin{tabular}{cccccc}
\hline Year & Irrigation $(\mathrm{mm})$ & Time used $(\mathrm{h})$ & EEL $\left(\mathrm{kWh} \mathrm{ha}{ }^{1}\right)$ & EEL $\left.(\mathrm{MJ} \mathrm{ha})^{1}\right)$ & ED $\left(\mathrm{MJ} \mathrm{ha}^{1}\right)$ \\
\hline $2011 / 2012$ & 270.9 & 630 & 927.36 & 3338.50 & 354.78 \\
\hline $2012 / 2013$ & 290.5 & 676 & 994.46 & 3580.06 & 380.69 \\
\hline
\end{tabular}

The highest energy ratio was obtained in the 2012/2013 harvest ( $p<0.05$ ); however, without effect under irrigation ( $p>$ 0.05) (Table 11). Contrary behavior was verified by Jordan et al. (2012a), in a study conducted with the sunflower crop, where the energy ratio was lower with irrigation.

TABLE 11. Used energy (UE), extracted energy (EE), energy ratio (ER) with and without irrigation in the sunflower crop.

\begin{tabular}{|c|c|c|c|c|c|c|}
\hline Genotype & $\begin{array}{c}\mathrm{UE}_{11 / 12} \\
\left(\mathrm{MJ} \mathrm{ha}^{1}\right)\end{array}$ & $\begin{array}{c}\mathrm{EE}_{11 / 12} \\
\left(\mathrm{MJ} \mathrm{ha}^{1}\right) \\
\end{array}$ & $\mathrm{ER}_{11 / 12}$ & $\begin{array}{r}\mathrm{UE}_{12 / 13} \\
\left(\mathrm{MJ} \mathrm{ha}^{1}\right) \\
\end{array}$ & $\begin{array}{c}\mathrm{EE}_{12 / 13} \\
\left(\mathrm{MJ} \mathrm{ha}^{1}\right) \\
\end{array}$ & $\mathrm{ER}_{12 / 13}$ \\
\hline With irrigation & 12358 & 77434 & $6.27 \mathrm{Aa}$ & 12026 & 96811 & $8.05 \mathrm{Ab}$ \\
\hline Without irrigation & 8665 & 44377 & $5.12 \mathrm{Aa}$ & 8065 & 74422 & $9.23 \mathrm{Ab}$ \\
\hline
\end{tabular}

Capital letter: among systems; small letter: among crops.

\section{CONCLUSIONS}

1. The sunflower genotypes showed similar yields in both years;

2. The cultivation of the irrigated sunflower crop is economically viable in a short and long term;

3. The irrigation does not alter the energy ratio of the sunflower crop;

4. The highest economic return and higher energy ratio occurs in the 2012/2013 crop due to higher yield. 


\section{REFERENCES}

AGRIANUAL (2012): Anuário da Agricultura Brasileira. São Pau lo: FNP consultoria e co mércio, 546p.

Albuquerque FA, Beltrão NEM, Vale DG (2007) Análise energética do algodoeiro na agricultura familiar em diferentes regiões nos estados do Ceará e Mato Grosso do Sul. Campina Grande, EMBRAPA. (Circular Técnica, 116).

Anastasi U, Santonoceto C, Giuffre AM, Sortino O, Abbate V(2010) Yield performance and grain lipid composition of standard and oleic sunflower as affected by water supply. Field Crops Research 119:145-153.

Assenheimer A, Campos AT, Gonçalves Júnior AFC (2009) Análise energética de sistemas de produção de soja convencional e orgânica. A mbiência 5(3):443-455.

Biscaro GA, Machado JR, Tosta MS, Mendonça V, Soratto RP, Carvalho LA (2008) Adubação nitrogenada em cobertura no giras sol irrigado nas condições de Cassilândia - MS. Ciência e Agrotecnologia 32:13661373.

Capellesso AJ, Cazella AA (2013) Indicador de sustentabilidade dos agroecossistemas: estudo de caso em áreas de cultivo de milho. Ciência Rural 43(12):22972303.

Chechetto RG, Siqueira R, Gamero CA (2010) Balanço energético para a produção de biodiesel pela cultura da mamona. Revista Ciência Agronômica 41:546-553.

De Aquino LA, Da Silva FDB, Berger PG (2013) Características agronômicas e o estado nutricional de cultivares de girassol irrigado. Revista Brasileira Engenharia Agrícola e A mbiental 17(5):551-557.

Dos Santos CAC, Peixoto CP, Vieira EL, Da Silva MR, Bulhões LS, Dos Santos JMDS, De Carvalho EV (2016) Produtividade do girassol sob a ação de bioestimu lante vegetal em diferentes condições de semeadura no sistema plantio direto. Revista de Ciências Agroambientais 14(2):83-91.

EMBRAPA - Empresa Brasileira de Pesquisa Agropecuária (2006) Sis tema brasileiro de classificação dos solos. Brasília, EMBRAPA. 306p.

Frizzone JA, Andrade Junior AS, Souza JLM, Zocoler JL (2005) Análise de projetos de irrigação. In_. Planejamento de irrigação. Brasília, EMBRAPA.

Gomes EP, Ávila MR, Rickli ME, Petri F, Fedri G (2010) Desenvolvimento e produtividade do girassol sob lâminas de irrigação em semeadura direta na região do Arenito Caiuá, Estado do Paraná. Irriga 15(4):373-385.

Gomes EP, Fredi G, Ávila MR, Biscaro GA, Rezende RK, Jordan RA (2012) Produtividade de grãos, óleo e massa seca de girassol sob diferentes lâminas de irrigação suplementar. Revista Brasileira de Engenharia Agrícola e Ambiental 16(3):237-246.

Gomes EP, Jordan RA, Moto miya A VA, Padua JB, Biscaro GA, Geisenhoff LO (2013) Análise econômica e viabilidade energética da cultura do feijoeiro co mu m sob irrigação. Revista Brasileira de Engenharia Agrícola e Ambiental 17(8):835-842.
Guedes Filho DH, Dos Santos JB, Gheyi HR, Cavalcante LF, Junior JAS (2015) Componentes de produção e rendimento do girassol sob irrigação com águas salinas e adubação nitrogenada. IRRIGA 20(3):514-527.

Hülsbergen KJ, Feil B, Biermann S, Rathke GW, Kalk WD, Diepenbrock WA (2001) Method of energy balancing in crop production and its application in a longterm fertilizer trial. Agriculture Ecosystems and Environment 86:303-321.

Jasper SP, Biaggioni MAM, Silva PRA (2010) comparação do custo de produção do crambe com outras culturas oleaginosas em sistema de plantio direto. Revista Energ ia na Agricultura 25:141-153.

Jordan RA, Go mes EP, Biscaro GA (2012a) Impact of irrigation on yield and energy balance of the production of oil and cake of two sunflower varieties. Engenharia Agrícola 38:1048-1057.

Jordan RA, Gomes EP, Biscaro GA, Motomiya A VA, Geisenhoff L (2012b) Impacto energético da irrigação por gotejamento no cultivo de mamona. Pesquis a Agropecuária Tropical 42:375-382.

Lira RM, Dos Santos AN, Da Silva JS, Barnabé JMC, Da Silva Barros M, Ramalho HA (2015) Utilização de águas de qualidade inferior na agricultura irrigada. Revista Geama 3(1):62-83.

Karam F, Lahoud R, Masaad R, Kabalan R, Breidi J, Chalita C, Rouphael Y (2007) Evapotranspiration, seed yield and water use efficiency of drip irrigated sunflower under full and defic it irrigation conditions. Agricultural Water Management 90:213-223.

Martin NB, Serra R, Antunes JFG, Oliveira MDM, Okawa H (1994) Custos: sistema de custo de produção agrícola. Informações Econômicas 24:97-122.

Melo D, Pereira JO, Souza EG, Gabriel Filho A, Nóbrega LHP, Pinheiro Neto R (2007) Energetic balance of soybean and corn production systems in a farm of the west of Paraná, Brazil. Acta Scientiaru m Agronomy 29:173178.

Oliveira CR, De Oliveira JL, Barbosa FR, Dario AS, Moura SG, Barros HB (2014) Efeito do nitrogênio em cobertura na produtividade de girassol, no Estado do Tocantins. Científica, 42(3): 233-241.

Pacheco EP (2000) Se leção e custo operacional de máquinas agrícolas. Rio Branco, Embrapa Acre. 21p. (Documentos, 58).

Pereira RM, Júnior JA, Casaroli D, Sales DL, Rodrigues WDM, Souza JMF (2015) Viabilidade econômica da irrigação de cana-de-açúcar no cerrado brasileiro. IRRIGA 1(2):149-157. 
Porto WS, Carvalho CGP, Pinto RJB (2007)

Adaptabilidade e estabilidade como critérios para seleção de genótipos de girassol. Pesquis a Agropecuária Brasileira 42:491-499.

Schwerz T, Jakelait is A, Teixeira MB, Soares FA, Tavares CJ (2015) Produção de giras sol cultivado após soja, milho e capim-marandu, com e sem irrigação suplementar. Revista Brasileira Engenharia Agrícola Ambiental 19(5):470-475.
Silva AS (2013) Avaliação do Programa Nacional de Produção e Uso de Biodiesel no Brasil. Revista de Política Agrícola 23:18-31.

Tokairin TDO, Cappello FP, Spósito MB (2014) Production cost for table guavas produced with and without bagging: case study. Revista Brasileira de Fruticultura 36(3):542-549. 